\title{
The potential association of Echinochloa polystachya (Kunth) Hitchc. with bacterial consortium for petroleum degradation in contaminated soil
}

\author{
Hauane da Silva Correa ${ }^{1} \cdot$ Leila Teresinha Maranho ${ }^{1,2}$ (I)
}

Received: 2 May 2020 / Accepted: 22 December 2020 / Published online: 11 January 2021

(c) The Author(s) $2021 \quad$ OPEN

\begin{abstract}
In recent years, environmental impacts related to the contamination of ecosystems by petroleum have become frequent. In contact with the environment, petroleum can cause toxic effects in the biodiversity and on human health and compromise both water and land resources. Among the strategies to overcome this issue, bioremediation stands out as viable and promising alternative for environmental decontamination. To bioremediate petroleum-contaminated sites, phytoremediation and bioaugmentation techniques can be used. Thus, this research aimed to evaluate through a pot experiment four bioremediation strategies: (1) natural attenuation, (2) phytoremediation with Echinochloa polystachya, (3) bioaugmentation with bacterial consortium and (4) bioaugmentation-assisted phytoremediation, for the treatment of a co-contaminated soil presenting $100 \mathrm{~g} \mathrm{~kg}^{-1}$ of petroleum. In addition, two control treatments were carried out with substrates not contaminated with petroleum: (5) control with E. polystachya and (6) control treatment with bacterial consortium and E. polystachya. The experiment lasted 60 days in a greenhouse. The survival rate of E. polystachya was $100 \%$ in the contaminant tolerance aspect, resulting in increased stomatal density and aerenchyma, affecting few parameters of the plant, which demonstrate its phytoremediation capacity. In all treatments, petroleum degradation occurred. The highest degree of total petroleum hydrocarbon removal was obtained for contaminated soil cultivated with E. polystachya (phytoremediation), followed by contaminated soil cultivated with E. polystachya and bacterial (bioaugmentation-assisted phytoremediation treatment) and contaminated soil treated with bacterial consortium (bioaugmentation). Natural attenuation was less effective, proving the efficiency of the phytoremediation by E. polystachya and bacterial consortium, that responded positively to the stresses generated by contamination. However, further studies should direct to aim understanding the metabolic processes involved in the degradation and that these approaches to assist in environmental decontamination.
\end{abstract}

Keywords Petroleum hydrocarbons $\cdot$ Rhizosphere $\cdot$ Bioaccumulation $\cdot$ Phytotoxicity $\cdot$ Phytotoxicity $\cdot$ Contamination

\section{Introduction}

Petroleum is the world's leading energy matrix, and it requires extensive logistics for production, transportation, storage and marketing [36]. With the intense exploration of petroleum, its presence in the environment has become increasingly common, whether through accidental spills or incorrect disposal of the generated waste [52]. The arrival of this contaminant in the environment is one of the major causes of water and soil pollution, which directly affects the fauna and flora. In addition to being a threat to ecosystems, it can cause serious damage to human health

\footnotetext{
$\triangle$ Leila Teresinha Maranho, leilamaranho@gmail.com.br| ${ }^{1}$ Undergraduate Degree in Biological Sciences, Positivo University, Professor Pedro Viriato Parigot de Souza, 5300, Curitiba, PR 81280-330, Brazil. ${ }^{2}$ Graduate Program in Industrial Biotechnology, Positivo University, Professor Pedro Viriato Parigot de Souza, 5300, Curitiba, PR 81280-330, Brazil.
} 
due to its high carcinogenic and neurotoxic potential [33]. Therefore, to reconcile the increase in petroleum demand with environmental protection, it is necessary to understand which techniques can remediate contaminated environments.

Petroleum consists, predominantly, of aliphatic or aromatic hydrocarbons, in addition to resins and metals such as nickel, iron and vanadium [50] and may persist in the environment for several years due to the slow biodegradation of its components, such as aromatic molecules, which have a high molecular mass [5]. Thus, it is necessary to apply techniques capable of accelerating the degradation of this contaminant when present in the soil, such as the use of microorganisms and plants that together can bring better results [49]. This method includes natural attenuation, bioaugmentation and phytoremediation techniques, which are the most effective approaches and that present more cost-benefit ratio in the treatment of petroleumcontaminated soils [16].

In environments contaminated with petroleum hydrocarbons, the phytoremediation strategy employed is rhizodegradation, an efficient technique for environmental decontamination, but that lacks a better understanding, especially about the interactions that occur between the plant, the microorganisms and the contaminant $[22,47]$. In this technique, there is a synergy between the plant and the microorganisms that live in the rhizosphere, i.e., the bacteria that survive in symbiosis with the plant. This synergy promotes several ecological functions, such as the biological nitrogen fixation and other biogeochemical processes $[26,41]$. Thus, they also provide increased nutrient absorption and tolerance to abiotic stress, and protection against pathogens.

Although efficient, the use of only one microorganism may have limited efficiency in bioremediation, since there may be competition with local microorganisms [16]. Therefore, the use of bacterial consortia, formed by strains isolated from different microorganisms previously selected due to their characteristics, can be more effective in removing contaminants, since there is a mutual and synergistic cooperation between the chosen bacteria [23,37].

The plants, in turn, favor the action of microorganisms because they provide oxygen and nutrients for microbial growth, which enhances the degradation of petroleum hydrocarbons. However, plants may be directly or indirectly affected by petroleum in the soil [20], resulting in developmental $[25,28]$, structural $[9,10,40]$ and physiological changes [45]. This occurs because an environment contaminated with petroleum exposes the plant to stresses, such as chemical, hydric (caused by the hydrofibricity of contaminants) and oxidative (excessive free radicals) ones, in addition to greater soil compaction and loss of nutrients [46].
Thus, the choice of plant is crucial for a successful phytoremediation technique, and to this end, it is necessary to understand the anatomical and physiological characteristics of the species. The plant chosen for phytoremediation must be resistant to the contaminant and have high biomass production capacity [11]. These two characteristics are present in Echinochloa polystachya (H.B.K.) Hitchcock (Poaceae), which has the capacity to phytoremediate petroleum-contaminated environments, mainly due to the microorganisms present in its rhizosphere $[8,35]$.

Therefore, by combining the phytoremediation plant with the bioaccumulation of microorganisms present in the rhizosphere, it is possible to increase the efficiency of the remediation technique on petroleum-contaminated soils. Thus, the objective of this study was to evaluate the effects of petroleum-contaminated soil inoculated with bacterial consortium on the growth, development and structural organization of Echinochloa polystachya, as well as to compare the degradation rate of petroleum hydrocarbons in the different treatments, in which the plant was cultivated with and without the bacterial consortium.

\section{Materials and methods}

\subsection{Obtaining the bacterial consortium}

To obtain the bacterial consortium, microspheres were produced from the bacterial biomass developed by Homan et al. [27], containing four species of bacteria extracted from the rhizosphere of Echinochloa polystachya: Stenotrophomonas acidaminiphila, Bacillus subtilis, Bacillus pumilus and Microbacterium aerolatum.

This solution was diluted in $1 \%$ alginate powder and then dripped with a $10 \mathrm{~mL}$ syringe arranged in a programmable pump, calibrated to produce drops every $0.5 \mathrm{~mL} \mathrm{~min}{ }^{-1}$. The drops were released in a $0.5 \%$ calcium chloride solution $\left(\mathrm{CaCl}_{2}\right)$ and then placed in a $1 \%$ acetic acid and $0.4 \%$ chitosan powder solution, where they remained for $\mathbf{4 0} \mathrm{min}$ and were stirred every five minutes. Finally, the spheres were recovered using a stainless steel sieve $(0.5 \mathrm{~mm})$ and washed with distilled water.

The microspheres were then stored in plastic containers at $-4^{\circ} \mathrm{C}$ for $24 \mathrm{~h}$. To increase the durability of the consortium, the product was dehydrated with the help of a freeze dryer until the microspheres were completely dried. Each microsphere weighed approximately $0.0076 \mathrm{G}$. Thus, $0.22 \mathrm{~g}$ of consortium was applied in each inoculated treatment, containing a total of $1.5 \times 10^{3}$ UFC. $g^{-1}$ among the four different types of bacteria present in the bacterial consortium. 


\subsection{Establishment of the experiments}

The study was carried out in a greenhouse at Positivo University (UP) with a structure covered with a transparent polyethylene film, activated against ultraviolet rays, with thickness of 150 micrometers, located in Curitiba, Paraná, south of Brazil ( $25^{\circ} 26^{\prime} 48.58^{\prime \prime} \mathrm{S}, 49^{\circ} 21^{\prime} 31.87^{\prime \prime} \mathrm{W} ; 910 \mathrm{~m}$ a.s.I.). The experiments were conducted in temperature between 25 and $30^{\circ} \mathrm{C}$, relative humidity between 85 and $90 \%$ and $12 \mathrm{~h}$ of uninterrupted darkness and $12 \mathrm{~h}$ of sunlight every day. The collected soil underwent $0.5 \mathrm{~mm}$ mesh screening and was contaminated with $100 \mathrm{mg} \mathrm{kg}^{-1}$ of petroleum.

The petroleum used for establishing the experiment presented the following characteristics: relative density $\left(20 / 4{ }^{\circ} \mathrm{C}\right) 0.90$; density $\left({ }^{\circ} \mathrm{API}\right) 23.8$; total acid number 1.02 ( $\mathrm{mg} \mathrm{KOH} \mathrm{g}^{-1}$ ); salt content 202 ( $\mathrm{mg} \mathrm{NaCl} \mathrm{L}^{-1}$ ); water and sediment content $0.60 \%$; saturated hydrocarbons $49.8 \%$; aromatic hydrocarbon $25.4 \%$; hydrocarbon resins $22.4 \%$; and asphaltenes $2.4 \%$. The plant treatments received a stake with two buds of Echinochloa polystachya.

Subsequently, these substrates were placed in polyvinyl chloride (PVC) vessels and six treatments were established (Fig. 1), with six repetitions each: (1) contaminated soil cultivated with E. polystachya and bacterial consortium (PPC); (2) contaminated soil cultivated with E. polystachya (PP); (3) contaminated soil treated with bacterial consortium (PC); (4) natural attenuation; (5) control treatment with $E$. polystachya; and (6) control treatment with bacterial consortium and E. polystachya. with six repetitions each.

Each treatment was repeated six times, being evaluated over a 60-day trial period. The plants were irrigated daily at field capacity of $85 \%$. In this phase, aspects related to tolerance, growth and development of plants were analyzed. All samples were measured weekly with a metric tape for stem length. The plants were uprooted 60 days after the establishment of the experiments.

\subsection{Development of Echinochloa polystachya}

The determination of the chlorophyll content was based on the method proposed by Barnes et al. [6]. $28 \mathrm{mg}$ obtained from fresh leaf samples collected from plants exposed to different treatments was preserved in tubes. To each sample, $5 \mathrm{ml}$ of dimethyl sulfoxide was added. The tubes remained in water bath for $6 \mathrm{~h}$, until the complete extraction of the pigment. The material absorbances were read using a spectrophotometer (Varian Cary 50B10) at $648 \mathrm{~nm}$ and $665 \mathrm{~nm}$ wavelengths. The respective absorbance values obtained were applied in Eqs. (1)-(3).

$C a=14.85 A 665-5.14 A 648$
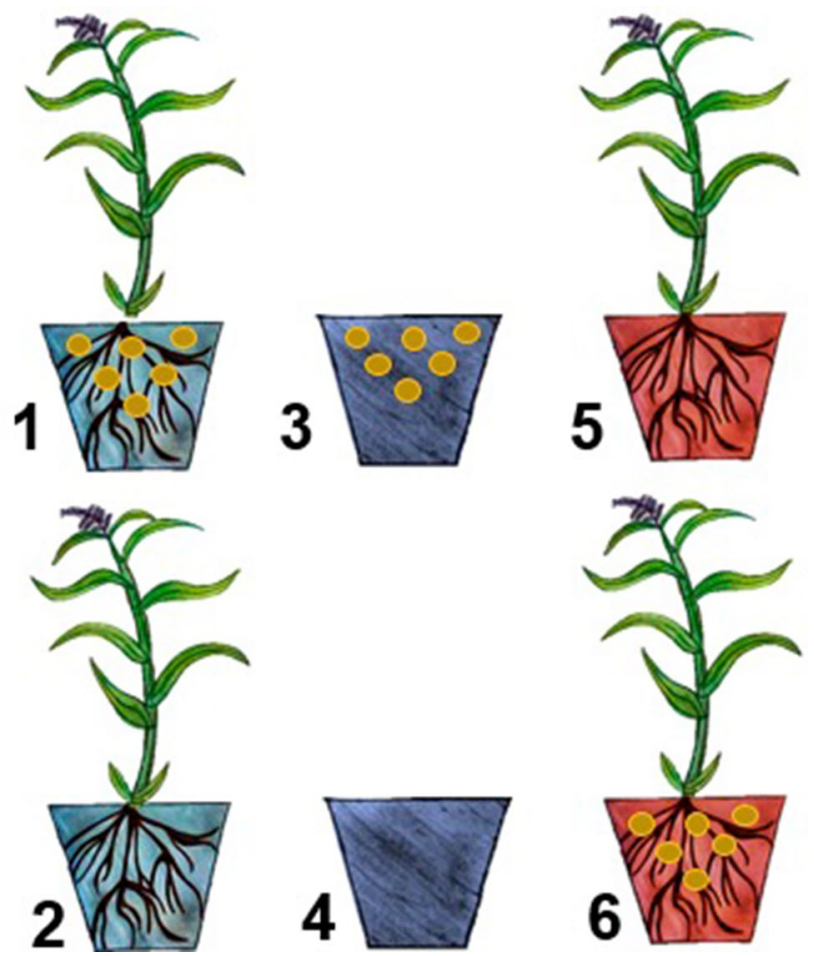

Fig. 1 Representative scheme of the treatments, (1) contaminated soil cultivated with $E$. polystachya and bacterial consortium (PPC); (2) contaminated soil cultivated with E. polystachya (PP); (3) contaminated soil treated with bacterial consortium (PC); (4) natural attenuation; (5) control treatment with E. polystachya; (6) control treatment with bacterial consortium and E. polystachya

$C b=25.48 A 648-7.36 A 665$

$C(a+b)=7.49 A 665+20.34 A 648$

$C a=$ Chlorophyll $a, C b=$ Chlorophyll $b$, and C $(a+b)=$ Total chlorophyll. For unit conversion, the values calculated for $\mathrm{Ca}$ and $\mathrm{Cb}$ were multiplied by the volume of solvent that was used $(5 \mathrm{~mL})$ and divided by the leaf weight of each test tube $(28 \mathrm{mg})$, obtaining the concentration of each pigment per unit of leaf weight in $\mathrm{ml}^{\mathrm{mg}} \mathrm{m}^{-1}$. The values obtained for chlorophyll $a$ and $b$ were multiplied by 1.121 and 1.104 (molecular weight), the unit being expressed in mmol.mg ${ }^{-1}$.

\subsection{Stomatal density}

The stomatal density in individuals exposed to petroleum and control was determined according to the methodology described by Franklin [21], and the stomata were counted in an area of $1 \mathrm{~mm}^{2}$ under a photonic microscope system (Olympus-CX41RF). 


\subsection{Anatomical analysis of Echinochloa polystachya}

The analyses of the structural organization of the plants were performed on roots samples collected at $2 \mathrm{~cm}$ from the apex, and on leaves collected from the 4 th stem node. These samples were fixed with FAA 70 for $48 \mathrm{~h}$ as described by Johansen [30] and kept in 70\% ethanol until final processing [7]. The aerial and root biomass were determined after drying the material at $70^{\circ} \mathrm{C}$ until constant weight.

The samples were embedded in glycol methacrylate (JB-4) [19] for the production of the permanent slides with synthetic resin (Entellan ${ }^{\circ}$ ). The sectioning was done using a rotating microtome, and the material was stained with toluidine blue. After this procedure, the slides were analyzed under an optical microscope, and the characteristics of the structural organization of $E$. polystachya leaves and roots in $0.7 \mu \mathrm{m}$ cross sections were observed.

\subsection{Degradation of petroleum hydrocarbons}

To analyze petroleum degradation, $5 \mathrm{~g}$ of soil was collected from each treatment in the rhizosphere region. The plants were removed from the pots, and the soil near the roots was collected. In the treatments without plants, soil was collected in the same region. After that, $2 \mathrm{~g}$ of anhydrous sodium sulfate $\left(\mathrm{Na}_{2} \mathrm{SO}_{4}\right)$ was added for the complete absorption of water from the samples, as well as $5 \mathrm{~mL}$ of dichloromethane solvent $\left(\mathrm{CH}_{2} \mathrm{Cl}_{2}\right)$ according to the chromatography standard. The samples were placed on an automatic shaker for $5 \mathrm{~h}$ at $300 \mathrm{rpm}$, and then, the material was centrifuged for $15 \mathrm{~min}$ at $3000 \mathrm{rpm}$.

After these procedures, all samples supernatant was removed with Pasteur pipettes. Subsequently, $5 \mathrm{~mL}$ of dichloromethane was added to the samples again and the liquid part was removed until the complete extraction of the petroleum. The samples were stored separately in amber glass and remained under refrigeration. Afterward, gas chromatography analysis was carried out separately with $0.5 \mathrm{~mL}$ of each sample to compare petroleum degradation in the different treatments. The chromatograph used had an HP-5 capillary column (5\% phenyl)-methylpolysiloxane ( $30 \mathrm{~m}, 25 \mathrm{~mm}$ id, $0.25 \mu \mathrm{m}$ thick). Each compound was identified based on its retention time, and the area reduction percentage was quantified. Natural attenuation peak areas (NA) were used as a point of reference for the remaining compounds (100\%) in the treated systems.

\subsection{Statistical analyses}

All data were analyzed in the BioStat 5.3 software. Mean and standard deviations were calculated. With these results, data distribution analysis was performed using the Shapiro-Wilk test. Subsequently, the one-way ANOVA test and the differences between means were compared using the Tukey test, at $5 \%$ significance $(p \leq 0.05)$.

\section{Results}

\subsection{Development of Echinochloa polystachya}

The survival rate reached $100 \%$ in all treatments, demonstrating the tolerance of E. polystachya to a petroleumcontaminated soil. The results regarding growth, aerial biomass, root biomass, chlorophyll a, chlorophyll b, total chlorophyll, stomatal density and stomatal characteristics are shown in Table 1.

Higher growth and biomass of the aerial part and root were observed in plants cultivated in petroleum-contaminated soil in a bacterial consortium in relation to the control treatment. On the other hand, the results obtained for the chlorophyll content demonstrate that there was no significant reduction in the content of photosynthesizing pigments in plants exposed to contamination (Table 1).

\subsection{Stomatal density}

Echinochloa polystachya leaves are amphistomatous. When viewed from the front, the epidermal cells have slightly sinuous rectangular-shaped walls on the adaxial and abaxial surfaces and are of various sizes. The stomata have dumbbell-shaped guard cells arranged in parallel rows (Fig. 2) and are located at the same level as the other epidermal cells. The stomatal density is 78 stomata per $\mathrm{mm}^{2}$ in control individuals (Table 1 ). In relation to the individuals exposed to petroleum, there was an increase of up to $24 \%$ in stomatal density (Fig. 2a) compared to control individuals (Fig. 2b). However, no significant differences were found in the size of the stomata in the different treatments, showing that petroleum does not affect the development of the plant in this parameter.

\subsection{Anatomical description of Echinochloa polystachya}

In cross section, the E. polystachya epidermis is uniseriate, formed by rounded cells with thick walls arranged at different heights, being visible through smaller cells above the fiber bundles. Throughout the mesophyll, epidermis and adaxial surface, it is possible to observe the presence of bulliform cells, which are large epidermal cells that usually occur in groups. The main vein, in cross section, is straight on the adaxial surface and has a large protuberance on the abaxial surface. In the straight region, the subepidermal cells constitute the pulvinar bands, whose cells have thin walls and are larger than in other regions 
Table 1 Growth, biomass, chlorophyll content, stomatal density, ostiole and guard cells size of the Echinochloa polystachya stomata cultivated in the different treatments

\begin{tabular}{|c|c|c|c|c|}
\hline Parameters & CT_plant & CT_-plant and consortium & $\begin{array}{l}\text { Plant on soil contami- } \\
\text { nated with petroleum }\end{array}$ & $\begin{array}{l}\text { Plant on soil contaminated } \\
\text { with petroleum and consor- } \\
\text { tium }\end{array}$ \\
\hline \multicolumn{5}{|l|}{$(\mathrm{cm})$} \\
\hline $\begin{array}{l}\text { Stem length } \\
\text { (g) }\end{array}$ & $22.5 \pm 12.33^{\mathrm{acd}}$ & $34.27 \pm 18.84^{\mathrm{bcd}}$ & $26.13 \pm 5.49^{\mathrm{cbd}}$ & $43.14 \pm 15.52^{\mathrm{dbc}}$ \\
\hline Aerial biomass & $3.19 \pm 1.44^{\mathrm{ad}}$ & $2.69 \pm 15.74^{\mathrm{bcd}}$ & $1.72 \pm 0.58^{\mathrm{cb}}$ & $4.07 \pm 1.66^{\mathrm{dab}}$ \\
\hline $\begin{array}{l}\text { Root biomass } \\
\mathrm{mmol} / \mathrm{mg}\end{array}$ & $0.71 \pm 0.41$ & $2.11 \pm 0.90$ & $1.40 \pm 0.40^{\mathrm{cb}}$ & $4.06 \pm 0.99^{\mathrm{ab}}$ \\
\hline Total chlorophyll & $20.25 \pm 6.05$ & $18.25 \pm 3.59$ & $19.05 \pm 2.11$ & $18.37 \pm 4.09$ \\
\hline Chlorophyll a & $17.64 \pm 5.24$ & $16.00 \pm 4.11$ & $16.83 \pm 1.68$ & $16.24 \pm 8.82$ \\
\hline $\begin{array}{l}\text { Chlorophyll b } \\
\text { uni. } / \mathrm{mm}^{2}\end{array}$ & $2.60 \pm 1.75$ & $2.25 \pm 1.72$ & $2.22 \pm 0.66$ & $2.13 \pm 1.29$ \\
\hline $\begin{array}{l}\text { Stomatal density } \\
\mu \mathrm{m}\end{array}$ & $78.00 \pm 15.74^{\mathrm{ab}}$ & $84.00 \pm 8.76^{\text {bacd }}$ & $97.00 \pm 21.52^{\mathrm{cbd}}$ & $96.00 \pm 8.39^{\mathrm{dbc}}$ \\
\hline Ostiolum length & $31.16 \pm 2.75^{\mathrm{ac}}$ & $38.5 \pm 3.34^{\text {bac }}$ & $32.66 \pm 3.65^{\mathrm{cbd}}$ & $34.83 \pm 1.46^{\mathrm{da}}$ \\
\hline Guard cell & $23 \pm 5.65^{\mathrm{abcd}}$ & $20.57 \pm 2.34$ & $20.78 \pm 1.62^{\mathrm{ca}}$ & $22.35 \pm 2.13$ \\
\hline
\end{tabular}

*Different letters next to the values in the same line indicate significant statistical differences by the Tukey test $(p \leq 0.05)$
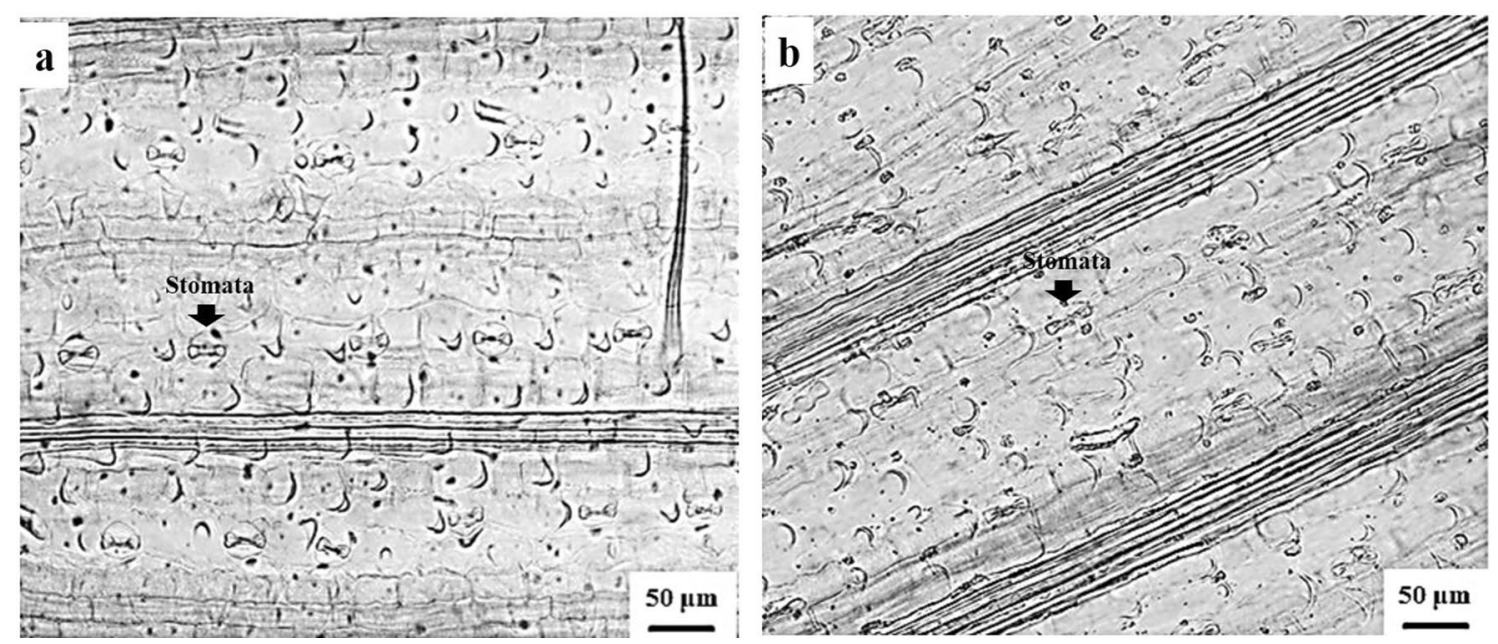

Fig. 2 Epidermis of E. polystachya with stomata arranged in parallel rows; a increased stomatal density in individuals exposed to petroleum contamination; b control treatment with E. polystachya

of the leaf, exerting motive function. In the region of the protuberance, the epidermal cells present thickened and lignified walls. In the median region of the limbus, 7 to 8 layers of cells and a large volume of aerenchyma are found (Fig. 3a).

In the mesophyll, there is a fundamental parenchyma and in the abaxial surface there are scattered fiber bundles in the chlorenchyma. The vascular bundle, which is normally oriented, does not differ from the others. Epidermal cells are larger and present thickening of the outer periclinal wall. The vascular bundles are collateral and closed (Fig. 4), and there are two types: smaller and larger ones, alternately arranged along the mesophyll. The largest bundles are surrounded by a double sheath, the outer one being the parenchyma and the inner one the sclerenchyma. The vascular bundles are formed usually by two large metaxylem vessels and protoxylem.

The individuals exposed to petroleum did not show changes in the number of central nerve cells layers. However, it is possible to see that control individuals have larger cells (Fig. 3a, b), while plants grown in petroleumcontaminated soil (Fig. 3C, d) had smaller and more compact cells. 

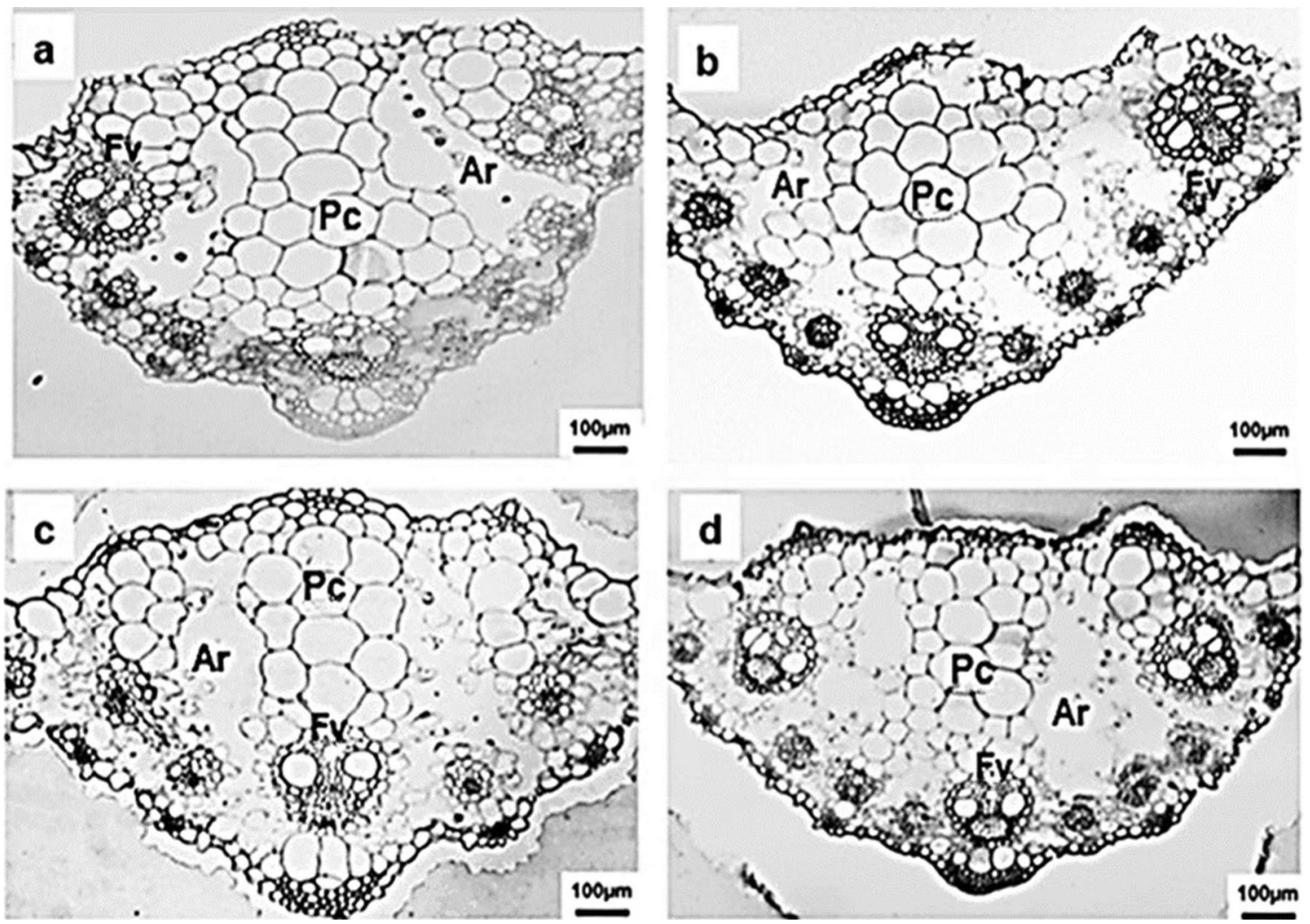

Fig. 3 Cross section of the main vein of E. polystachya. a Control treatment with $E$. polystachya; b control treatment with bacterial consortium and $E$. polystachya; c treatment contaminated soil cultivated with E. polystachya; $\mathbf{d}$ treatment contaminated soil cultivated

with E. polystachya and bacterial consortium. Pc, chlorophyll parenchyma; Air, aerenchyma between parenchymal cells; Fv, vascular bundles
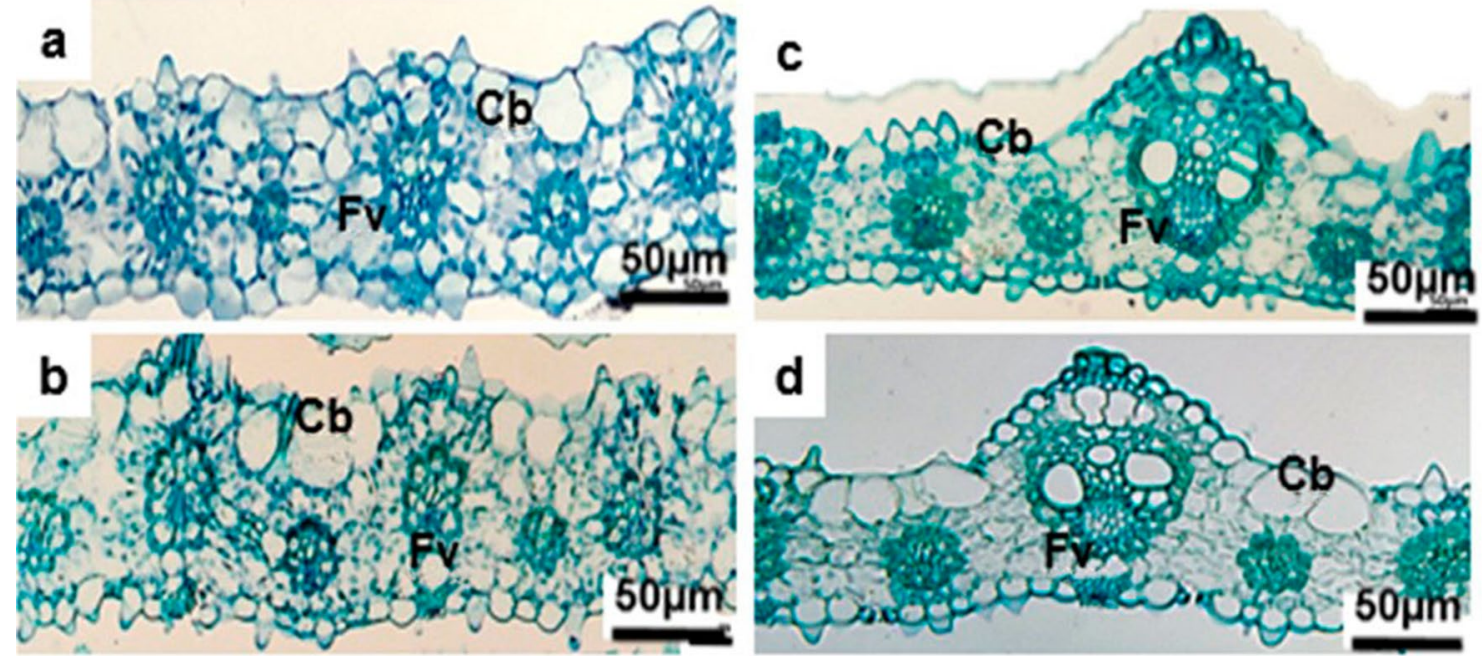

Fig. 4 Cross section of the E. polystachya mesophyll. a Control treatment with E. polystachya; b control treatment with bacterial consortium and $E$. polystachya; c treatment contaminated soil culti-

vated with E. polystachya; $\mathbf{d}$ treatment contaminated soil cultivated with $E$. polystachya and bacterial consortium. Cb, bulliform cells; Fv, vascular bundle 
The roots of E. polystachya have a layer of outer cells, the exodermis, in which the cell walls are more lignified and thicker. In all roots, few trichomes were observed. The root cortex, located under the exodermis, consists of 9 to 10 layers of parenchymal cells, which were rounded and presented a solid disposition. In the cortex, we also identified the presence of aerenchyma, next to cells with collapsed walls. The innermost portion of the cortex is in contact with the uniseriate endodermis, which is a thick U-shaped layer and delimits the central cylinder. The pericycle is located under the endoderm and consists of a uniseriate layer of cells (Fig. 5). This cylinder is responsible for the growth of lateral roots and for surrounding the vascular bundles of the root. The vascular system consists of the poles of the protoxylem to the inside of the metaxylem, where the phloem is found near the outermost ring.

In individuals exposed to petroleum, a small increase in the number of cells in the cortex was found, with 10 to 12 layers of cells. We have also observed a higher amount of aerenchyma in these individuals.

\subsection{Degradation of petroleum hydrocarbons}

The efficiencies of all treatments can be seen in Table 2, where the efficiency of the degradation of hydrocarbons of petroleum among the different treatments applied: contaminated soil cultivated with E. polystachya (PP); contaminated soil treated with bacterial consortium (PC); and contaminated soil cultivated with E. polystachya and bacterial consortium (PPC), in relation to the petroleum degradation obtained in natural attenuation (AT).

The natural attenuation treatment had the lowest degradation rate in relation to other treatments, with no significant difference in degradation in some retention times. The treatment only with bacterial consortium (PC) had less degradation efficiencies of petroleum hydrocarbons when compared to the treatments in which plants were used. However, in some petroleum chains, the treatment with PC showed a degradation of up to $57 \%$ compared to natural attenuation.

The treatments in which E. polystachya was used had high rates of degradation. Only the phytoremediation technique showed degradation in almost all retention
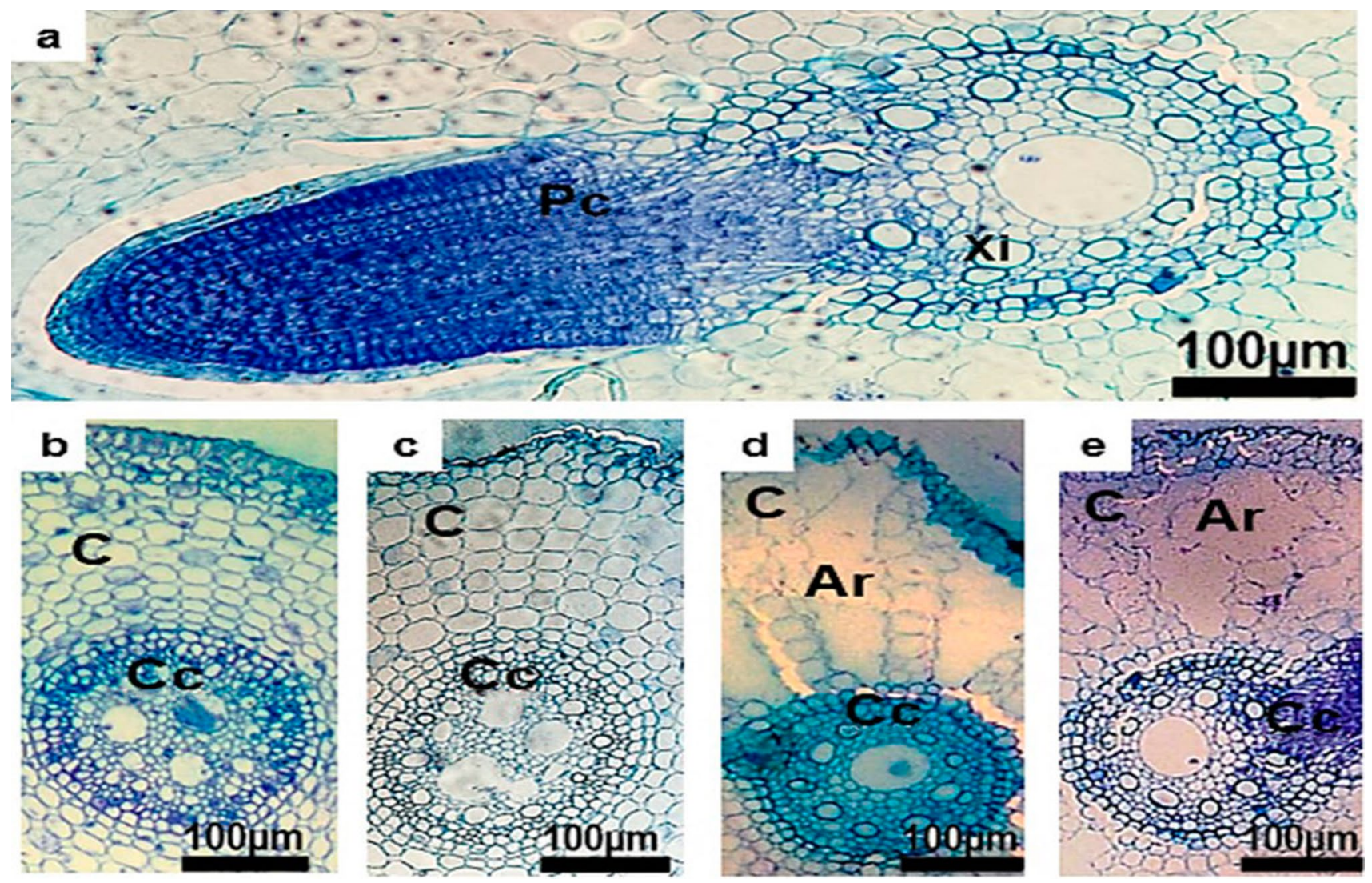

Fig. 5 Adventitious root of E. polystachya. a Activity of the pericycle and of the endoderm with U-shaped reinforcement; $\mathbf{b}$ control treatment with E. polystachya; c control treatment with bacterial consortium and E. polystachya; $\mathbf{d}$ treatment contaminated soil cultivated

with E. polystachya; e treatment contaminated soil cultivated with E. polystachya and bacterial consortium. Pc, pericycle; Xi, xylem; C, cortex; Cc, central cylinder; Ar, aerenchyma 
Table 2 Efficiency in petroleum degradation among the different treatments, compared by retention time and area size

\begin{tabular}{|c|c|c|c|c|c|c|c|}
\hline \multirow{2}{*}{$\begin{array}{l}\text { Retention time } \\
\text { (min) }\end{array}$} & \multirow[t]{2}{*}{ AT } & \multicolumn{2}{|l|}{ PP } & \multicolumn{2}{|l|}{ PC } & \multicolumn{2}{|l|}{ PPC } \\
\hline & & & $\%$ & & $\%$ & & $\%$ \\
\hline 3.422 & $6782^{a}$ & $3475^{\mathrm{bcd}}$ & 49 & $5684^{\mathrm{cbd}}$ & 0 & $8619^{d b c}$ & 0 \\
\hline 5.003 & $8935^{\mathrm{ab}}$ & $5281^{\text {bacd }}$ & 41 & $6798^{\mathrm{cdb}}$ & 0 & $7639^{\mathrm{dbc}}$ & 15 \\
\hline 5.876 & $12497^{\mathrm{ab}}$ & $5475^{\text {bacd }}$ & 56 & $12512^{\mathrm{cbd}}$ & 0 & $10314^{\mathrm{dbc}}$ & 17 \\
\hline 6.525 & $18431^{\mathrm{a}}$ & $8408^{b c d}$ & 54 & $13642^{\mathrm{cbd}}$ & 0 & $12678^{\mathrm{dbc}}$ & 31 \\
\hline 7.089 & $28131^{a}$ & $12499^{b c d}$ & 56 & $12980^{\mathrm{cbd}}$ & 52 & $19339^{\mathrm{dbc}}$ & 31 \\
\hline 7.512 & $23622^{\mathrm{a}}$ & $11347_{\mathrm{bcd}}$ & 52 & $21069^{c b d}$ & 0 & $17711^{d b c}$ & 25 \\
\hline 8.572 & $46078^{\mathrm{abcd}}$ & $30447^{\text {bacd }}$ & 34 & $29716^{\text {cabd }}$ & 0 & $47796^{\text {dabc }}$ & 0 \\
\hline 9.510 & $64431^{\mathrm{abd}}$ & $34767^{\text {bacd }}$ & 41 & $73855^{\mathrm{cbd}}$ & 26 & $30388^{\text {dabc }}$ & 48 \\
\hline 10.110 & $8547^{\mathrm{ac}}$ & $26383^{b c}$ & 69 & $24671^{\text {cabd }}$ & 0 & $47620^{d c}$ & 44 \\
\hline 10.546 & $123327^{\mathrm{acd}}$ & $47614^{b c d}$ & 51 & $15682^{\text {cabd }}$ & 0 & $24625^{\text {dabc }}$ & 54 \\
\hline 12.027 & $21043^{\mathrm{ab}}$ & $15572^{\text {bacd }}$ & 35 & $12811^{\mathrm{cbd}}$ & 21 & $18748^{\mathrm{dbc}}$ & 39 \\
\hline 12.578 & $21406^{\mathrm{abd}}$ & $9029^{\text {bacd }}$ & 65 & $23372^{\mathrm{cbd}}$ & 0 & $17010^{\text {dabc }}$ & 40 \\
\hline 13.542 & $24568^{a}$ & $22464,5^{\mathrm{bcd}}$ & 9 & $16756^{\mathrm{cbd}}$ & 0 & $6151^{d b c}$ & 75 \\
\hline 16.085 & $13243^{a}$ & $13415^{\mathrm{bcd}}$ & 0 & $9306^{\mathrm{cbd}}$ & 0 & $8221^{d b c}$ & 38 \\
\hline 17.236 & $65573^{\mathrm{ad}}$ & $20929^{b c d}$ & 68 & $33489^{c b d}$ & 0 & $74231^{\text {dabc }}$ & 0 \\
\hline 18.086 & $33507^{\mathrm{ab}}$ & $25596^{\text {bacd }}$ & 24 & $52563^{\mathrm{cbd}}$ & 57 & $39091^{\mathrm{dbc}}$ & 0 \\
\hline 19.339 & $37624^{\mathrm{abcd}}$ & $19053^{\text {bacd }}$ & 51 & $17285^{\text {cabd }}$ & 0 & $51279^{d a b c}$ & 0 \\
\hline 20.265 & $31658^{\mathrm{abd}}$ & $14830^{\text {bacd }}$ & 53 & $13364^{\mathrm{cbd}}$ & 0 & $46338^{\text {dabc }}$ & 0 \\
\hline 22.717 & $13248^{\mathrm{abd}}$ & $5872^{\text {bacd }}$ & 56 & $10558^{\mathrm{cbd}}$ & 0 & $22300^{\text {dabc }}$ & 0 \\
\hline 24.367 & $5532^{\mathrm{abc}}$ & $3000^{\text {bacd }}$ & 46 & $2936^{\text {cabd }}$ & 0 & $7078^{\mathrm{dbc}}$ & 0 \\
\hline
\end{tabular}

Natural attenuation (AT) was compared to the remaining treatments: PP contaminated soil cultivated with E. polystachya; PC contaminated soil treated with bacterial consortium; and PPC contaminated soil cultivated with E. polystachya and bacterial consortium

$\%$ Efficiency in petroleum degradation

*Different letters next to the values in the same line indicate significant statistical differences by the Tukey test $(p \leq 0.05)$ times, with an efficiency of up to $69 \%$ when compared to natural attenuation. However, the treatment in which bioaugmentation and phytoremediation (PPC) techniques were used together obtained a degradation efficiency of up to $75 \%$.

\section{Discussion}

\subsection{Plant analyses}

The results showed that the presence of petroleum in the soil promotes an increase in the growth, mainly stem length and root biomass of E. polystachya. This one can be observed especially in treatment "plant on soil contaminated with petroleum and consortium" where the bacterial consortium further increased the growth and biomass increment (Table 1). When present in environments contaminated with oil, some plants can develop responses to the scarcity of water and oxygen they are being subjected to, as changes in the roots, stems and leaves. These changes can be interpreted as strategies developed by plants to tolerate the toxic effects of petroleum. Lopes and Piedade [35] and Biazão et al. [8] found similar results when they evaluated the growth of E. polystachya cultivated in substrates contaminated with petroleum.

The inoculation of the bacterial consortium promoted the increase in E. polystachya biomass. Plants provide oxygen and release through their roots, substances containing sugars, amino acids and organic acids. These, as exchange, are metabolized by microorganisms, thus improving the degradation of the pollutant [47]. Moreover, the organic compounds in the pollutant can be used as a carbon source in this process, which is responsible for reducing the effects of the contaminants retained in the soil [32]. Thus, the microorganisms stimulate the growth and development of plants to improve the uptake of water and nutrients from the soil $[24,31]$.

Maqbool et al. [39], in a study on the effect of the inoculation by free and immobilized bacterial culture on the rhizodegradation of petroleum-polluted soil using Sesbania cannabina plant, found root biomass increased with the plant growth, during experimental period between 
the treatments with different petroleum-polluted soil concentrations.

The chlorophyll content results showed that there is no significant difference in the pigment content of plants grown in petroleum-contaminated soil compared to control individuals. Normally, the soil contaminated by petroleum decreases the chlorophyll content and can lead to a reduction in the concentration of photosynthetic pigments in the plant [45], because hydrocarbons tend to accumulate in the chloroplasts [4]. The level of chlorophyll reduction in plants can be used as an indicator of petroleum contamination $[2,42]$. However, our results demonstrate that petroleum does not affect the development of E. polystachya in this respect.

The increase in stomatal density shows that the plants developed mechanisms to survive the environmental conditions generated by the petroleum present in the soil (Table 1). Maranho et al. [40] repost that the toxic effects of petroleum can affect the morphology of the leaves with an increased number of intercellular spaces and increased stomata density. According to Larcher [34], this increase corresponds to an adaptive change under conditions of water scarcity, in which the stomata may be smaller in size and higher in density. This modification enables a faster reduction of perspiration, facilitating the closure of the stomata. However, in the present study, no significant differences were found for E. polystachya regarding the size of the stomata (Table 1) in the different treatments, not being affected by petroleum in this parameter. Zhang et al. [53], studying Zea mays L. (Poaceae) in soil contaminated by petroleum, found that stomatal density was negatively correlated with the petroleum level in soil.

In the anatomical analyses, no differences were found in the number of cells in the leaf midrib, but it was possible to visualize a decrease in the size of the parenchyma cells in relation to the control individuals (Fig. 4). The higher volume of intercellular spaces forming the aerenchyma (Fig. 3) is a response mechanism for plants grown in contaminated soil, which store larger amounts of oxygen inside and decrease the number of surrounding cells to survive the environment with petroleum. The same result was found when the root anatomy was analyzed, which evidenced a greater aerenchyma volume (Fig. 5), consistent with the results found for the higher root biomass in individuals exposed to petroleum (Table 1). The anoxic environment formed by petroleum also induced an increase in intercellular spaces, a reduction in the thickness of the central cylinder and an increase in the thickness of the root cortex (Fig. 5). Plants with dense and branched roots are considered suitable for the phytoremediation of organic pollutants as they provide a larger rhizospheric area, and thus a greater colonization of microorganisms $[24,51]$, since they provide oxygen to the rhizoplane.
Although aromatic hydrocarbons are degraded, the proportion of this process decreases in proportion to the low availability of oxygen in the contaminated environment. Phytoremediation technology uses the morphophysiological potential of plants to favor the degradation of pollutants. Plants participate in the remediation process through their roots, with the diffusion of oxygen into the sediment, where the microorganisms are present.

\subsection{Degradation of petroleum hydrocarbons}

Studies show that natural attenuation minimizes the concentration of the contaminant in the soil, but this technique involves only natural processes and may take years to partially or totally remedy a contaminated environment [29]. Therefore, it is important to intervene in this process in order to increase the degradation of petroleum in a given environment. The plant treatments showed better results when compared with the treatment with only bacterial consortium (Fig. 6). This is because the bacteria used depend on the rhizosphere of E. polystachya to develop, since they provide oxygen and other nutrients to the soil.

It was also possible to verify that the E. polystachya plant can phytoremediate independently from the bacterial consortium. In a revegetation study in petroleumcontaminated areas, Panchenko et al. [43] found that members of the Poaceae family were the most resistant to contamination, particularly Echinochloa crus-galli, which was found in areas with up to $200 \mathrm{~g} \mathrm{~kg}^{-1}$ of petroleum with high survival rates.

Elumalai et al. [17] cite that the bioaugmentation is a very promising technology for the removal of long-chain hydrocarbons and $\mathrm{n}$-alkanes from oil-contaminated environments but requires highly efficient microbes.

When using the phytoremediation and bioaugmentation techniques together, it is possible to increase the efficiency of degradation, which has been verified by Escalante-Espinosa et al. [18] when using Cyperus laxus (order Poales) in soil contaminated with petroleum and inoculated with bacterial consortium, whose degradation was more efficient when compared to other treatments. According to Tahir et al. [48], microorganisms are essential for environmental recovery and restoration because they easily adapt to the stresses caused by the presence of contaminants in the environment and have the resistance capacity and metabolic potential inherited by natural selection.

Thus, according to Santos and Maranho [47], the application of bacterial consortia in petroleum-contaminated environments has brought satisfactory results. Additionally, according to Chandra et al. [15], the consortia allow associations between different species, increase in the enzymes capable of degrading petroleum hydrocarbons. 

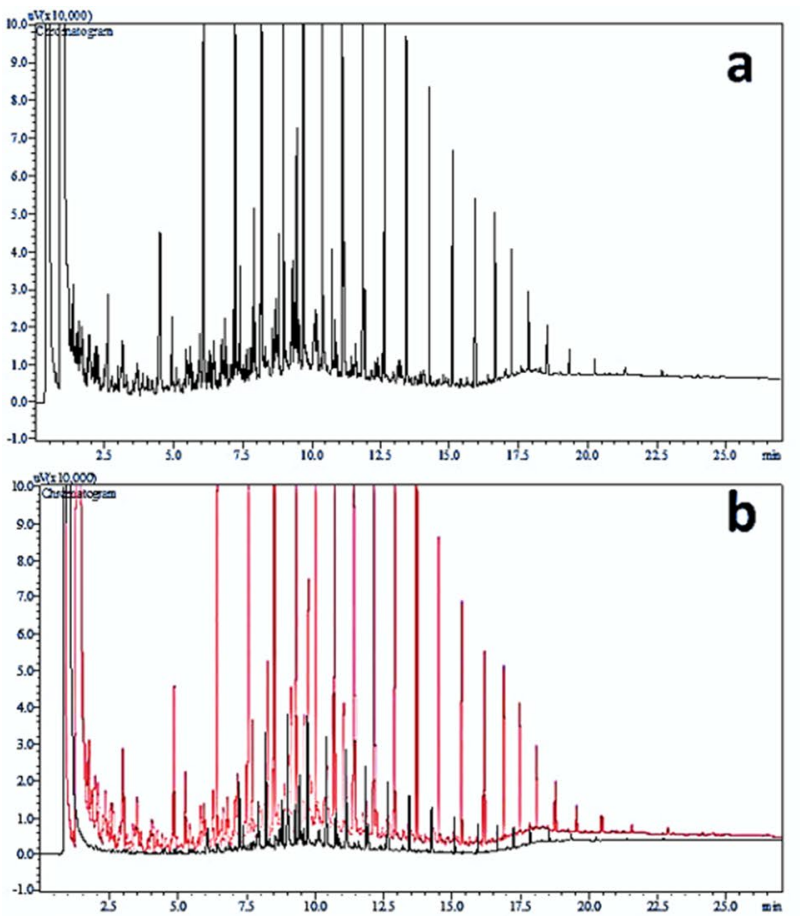

Fig. 6 Chromatograms of petroleum degradation, a natural attenuation; b contaminated soil cultivated with E. polystachya (PP); c contaminated soil treated with bacterial consortium (PC); d contami-

Cerqueira et al. [14] showed that the microbial consortium composed by five bacteria (Stenotrophomonas acidaminiphila, Bacillus megaterium, Bacillus cibi, Pseudomonas aeruginosa and Bacillus cereus) degraded, in liquid medium, high concentration of petroleum compounds producing biosurfactant efficiently. The consortium used in this research was composed of Stenotrophomonas acidaminiphila, Bacillus subtilis, Bacillus pumilus and Microbacterium aerolatum.

Mangwani et al. [38] when investigating the biofilm formation and polycyclic aromatic hydrocarbons (PAHs) degradation found that the marine bacterium Stenotrophomonas acidaminiphila was able to degrade PAHs. The authors highlight its bioremediation process application. Parthipan et al. [44] cite that $B$. subtilis produces high amounts of biosurfactant and degradative enzymes such as alkane hydroxylase and alcohol dehydrogenase in the presence of crude oil as a substrate. Calvo et al. [13] evaluated the surfactant activity of a Bacillus pumilus strain isolated from oil sludge and found that this bacterium grew well in the presence of crude oil under aerobic conditions and utilized the oil compounds as carbon and energy source. Ali et al. [3] monitored the dynamics of the hydrocarbonoclastic bacterial communities in desert soil sample was saturated with crude
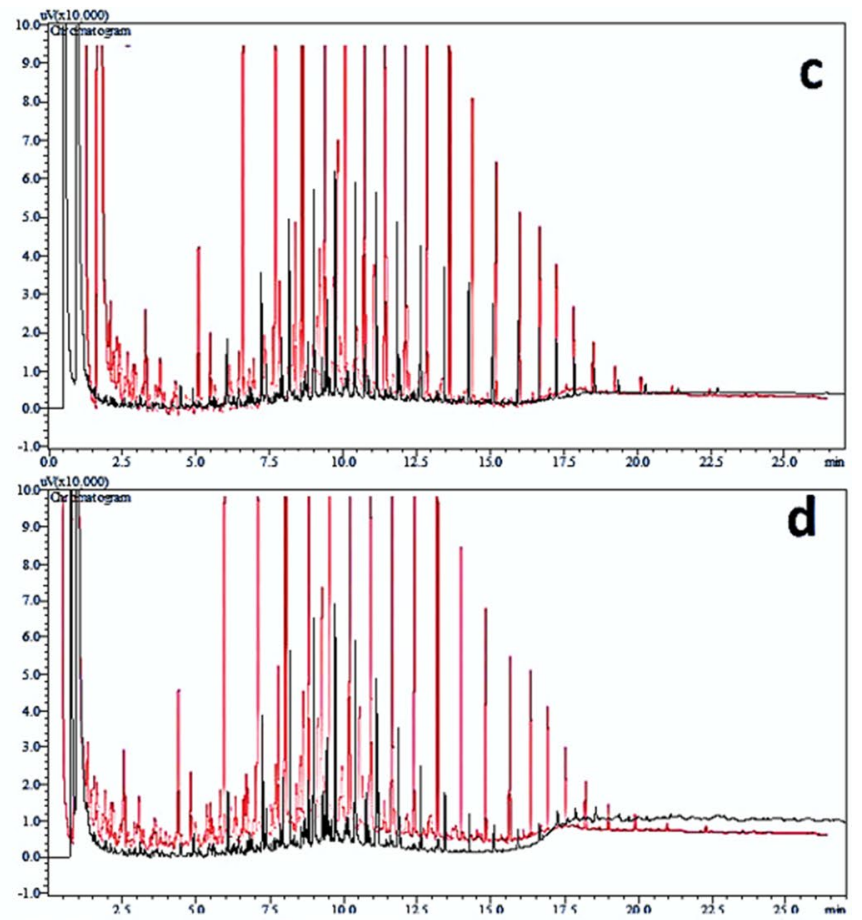

nated soil cultivated with $E$. polystachya and bacterial consortium (PPC). ${ }^{*} \mathbf{b}-\mathbf{d}$ Natural attenuation (AT) in red was compared to the remaining treatments in black

oil, and they identified the bacterial species and found Microbacterium aerolatum as main contributor to the oil consumption.

While studying natural attenuation, phytoremediation and bioaugmentation using Festuca arundinacea and microbial consortium [12] found that the phytoremediation and bioaugmentation are effective in remediating saline soil contaminated by heavy crude oil. Agnello et al. [1] when evaluating the natural attenuation, phytoremediation, bioaugmentation and phytoremediation + bioaugmentation found that the highest degree of removal of total petroleum hydrocarbons from PHCs was obtained by combining plant-bacterial interaction, being the most advantageous option for oil treatment contaminated soil.

The interaction between plant and bacteria is the most advantageous option for the treatment of petroleumcontaminated soils. In recent years, scientists have been investigating how the various bacteria contribute to phytoremediation (rhizodegradation), and the effectiveness of these approaches has been mainly demonstrated under laboratory conditions (ex situ). Nevertheless, further studies are required considering practical applications (in situ) of bioremediation to contain environmental contaminations. This should enable a deeper understanding of the interactions between plant, bacteria, contaminant and 
soil, and how to tailor each parameter to improve biodegradation efficiency and minimize its negative impacts. Therefore, increasing efforts should be conducted to select, identify and understand the role of rhizospheric microorganisms to expand the database regarding their petroleum-degrading potential to degrade petroleum and for bioprospection.

\section{Conclusion}

The use of E. polystachya for phytoremediation of soil contaminated with petroleum was proved effective. The plant responded positively to the stresses generated by contamination. All individuals survived contamination with little effect on their development and growth, showing the high resistance of this plant to contaminants. Rhizodegradation is a low-cost, easy to apply and effective technique in petroleum remediation. In the rhizosphere, there is a synergy between microorganisms and plants, creating a favorable environment for their growth.

Thus, when the phytoremediation and bioaugmentation techniques are used jointly, it is possible to obtain high rates of petroleum degradation. Microorganisms stimulate the bioavailability of the soil because they increase degradation rate and promote the partial or complete elimination of this contaminant in soils.

Acknowledgements We would like to thank Positivo University for their support and investment in this study and CNPq for their Technological Initiation grant. In addition, the authors would like to thank the Academic Publishing Advisory Center (Centro de Assessoria de Publicação Acadêmica, CAPA-www.capa.ufpr.br) of the Federal University of Paraná (UFPR) for assistance with English language translating and editing.

\section{Compliance with ethical standards}

Conflict of interest The authors declare that they have no known competing financial interests or personal relationships that could have appeared to influence the work reported in this paper.

Open Access This article is licensed under a Creative Commons Attribution 4.0 International License, which permits use, sharing, adaptation, distribution and reproduction in any medium or format, as long as you give appropriate credit to the original author(s) and the source, provide a link to the Creative Commons licence, and indicate if changes were made. The images or other third party material in this article are included in the article's Creative Commons licence, unless indicated otherwise in a credit line to the material. If material is not included in the article's Creative Commons licence and your intended use is not permitted by statutory regulation or exceeds the permitted use, you will need to obtain permission directly from the copyright holder. To view a copy of this licence, visit http://creativecommons .org/licenses/by/4.0/.

\section{References}

1. Agnello AC, Bagard M, Van Hullebusch ED, Esposito G, Huguenot D (2016) Comparative bioremediation of heavy metals and petroleum hydrocarbons co-contaminated soil by natural attenuation, phytoremediation, bioaugmentation and bioaugmentation-assisted phytoremediation. Sci Total Environ 563-564:693-703

2. Al-Hawas GHS, Shukry WM, Azzoz MM, Al-Moaik RMS (2012) The effect of sublethal concentrations of crude oil on the metabolism of Jojoba (Simmodsia chinensis) seedlings. Int Res J Plant Sci 34:54-62

3. Ali N, Dashti N, Khanafer M, Al-Awadhi Radwan S (2020) Bioremediation of soils saturated with spilled crude oil. Sci Rep 10:1116

4. Arellano P, Tansey K, Balzter H, Boyd DS (2015) Detecting the effects of hydrocarbon pollution in the Amazon forest using hyperspectral satellite images. Environ Pollut 205:225-239

5. Balachandran C, Duraipandiyan V, Balakrishna K, Ignacimuthu S (2012) Petroleum and polycyclic aromatic hydrocarbons (PAHs) degradation and naphthalene metabolism in Streptomyces sp. (ERI-CPDA-1) isolated from oil contaminated soil. Biores Technol 112:83-90

6. Barnes JD, Balaguer L, Manrique E, Elvira S, Davison AW (1992) A reappraisal of the use of DMSO for the extraction and determination of chlorophylls $\mathrm{a}$ and $\mathrm{b}$ in lichens and higher plants. Environ Exp Bot 32:85-100

7. Berlyn GP, Miksche JP (1976) Botanical microtechnique and cytochemistry. The lowa State University Press, Ames, p 326

8. Biazão TC, Weinschutz, Regina, Rocha-Uriartt L, Maranho LT (2016) Avaliação do Potencial de Echinochloa polystachya (Kunth) Hitchc. (Poaceae) para a Fitorremediação de Solo Contaminado com Petróleo. In: Kolicheski MB, Feilstrecker M, Erbe MCL, Amaral KJ, Neuffer D, Kawano M (Org.). Meio Ambiente Urbano e Industrial: Soluções, Tecnologias e Estratégias Aplicadas à Gestão. 1ed, Curitiba: Tecnologia 1: 111-128

9. Bona C, Silva MB, Rezende IM, Santos GO, Souza LA, Inckot RC (2008) Efeito do solo contaminado com óleo diesel na estrutura da raiz e da folha de plântulas de Sebastiania commersoniana (Euphorbiaceae) e Schinus terebinthifolius (Anacardiaceae). Acta Botanica Brasílica 25:277-285

10. Bramley-Alves J, Wasley J, King CK, Powell S, Robinson SA (2014) Phytoremediation of hydrocarbon contaminants in subantarctic soils: an effective management option. J Environ Manag 142:60-69

11. Brzeszcz J, Steliga T, Kapusta P, Turkiewicz A, Kaszycki P (2016) $\mathrm{R}$-strategist versus $\mathrm{K}$-strategist for the application in bioremediation of hydrocarbon contaminated soils. Int Biodeterior Biodegrad 106:41-52

12. Cai B, Ma J, Yan G, Dai X, Li M, Guo S (2016) Comparison of phytoremediation, bioaugmentation and natural attenuation for remediating saline soil contaminated by heavy crude oil. Biochem Eng J 112:170-177

13. Calvo C, Toledo FL, González-López J (2004) Surfactant activity of a naphthalene degrading Bacillus pumilus strain isolated from oil sludge. J Biotechnol 109:255-262

14. Cerqueira VS, Hollenbach EB, Maboni F, Vainstein MH, Camargo FAO, Peralba MCR, Bento FM (2011) Biodegradation potential of oily sludge by pure and mixed bacterial cultures. Biores Technol 102:10777-11050

15. Chandra S, Sharma R, Singh K, Sharma A (2013) Application of bioremediation technology in the environment contaminated with petroleum hydrocarbon. Ann Microbiol 63:417-431 
16. Da Silva BM, Maranho LT (2019) Petroleum-contaminated sites: decision framework for selecting remediation technologies. J Hazard Mater 378:120722

17. Elumalai P, Parthipan P, Obulisamy KP, Rajasekar A (2017) Enzyme-mediated biodegradation of long-chain n-alcanos $\left(C_{32}\right.$ e $\left.C_{40}\right)$ by thermophilic bacteria. 3 Biotech 7:116

18. Escalante-Espinosa E, Rodríguez-Gárcia L, Gutiérrez-Rojas M (2004) Improvement of the hydrocarbon phytoremediation rate by Cyperus laxus Lam. inoculated with a microbial consortium in a model system. Chemosphere 59:405-413

19. Feder N, O'Brien TP (1968) Plant microtechnique: some principles and new methods. Am J Bot 55:123-142

20. Fowzia A, Fakhruddin ANM (2018) A Review on Environmental Contamination of Petroleum Hydrocarbons and its Biodegradation. International Journal of Environmental Sciences \& Natural Resources 11:555811

21. Franklin GL (1946) A rapid method of softening wood for microtome sectioning. Trop Woods 88:35-36

22. García-Sanchez M, Košnáŕ Z, Mercl F, Aranda E, Tlustos PA (2018) Comparative study to evaluate natural attenuation, mycoaugmentation, phytoremediation, and microbial-assisted phytoremediation strategies for the bioremediation of an aged $\mathrm{PAH}-$ polluted soil. Ecotoxicol Environ Saf 147:165-174

23. Geraldo MG, Maranho LT (2020) Immobilization of the consortium of petroleum degrading bacteria obtained from rhizosphere from Panicum aquaticum Poir., Poaceae. Braz J Dev 6:45816-45830

24. Glick BR (2010) Using soil bacteria to facilitate phytoremediation. Biotechnol Adv 28:367-374

25. Gogosz AM, Bona C, Santos GO, Botosso PC (2010) Germination and initial growth of Campomanesia xanthocarpa O. Berg. (Myrtaceae), in petroleum-contaminated soil and bioremediated soil. Braz J Biol 70:977-986

26. Gouda S, Kerry RG, Das G, Paramithiotis S, Shin HS, Patra JK (2018) Revitalization of plant growth promoting rhizobacteria for sustainable development in agriculture. Microbiol Res 206:131-140

27. Homan S, Levandowski A, Maranho LT (2019) Selection of oil degrading bacteria extracted from the rhizosphere of Echinochloa polystachya (Kunth) Hitchc. Ambiência 15:207-221

28. Inckot RC, Santos GO, Souza LA, Bona C (2011) Germination and development of mimosa pilulifera in petroleum-contaminated soil and bioremediated soil. Flora 206:261-266

29. Jacques RJS, Bento FM, Antoniolli ZI, Camargo FAO (2007) Biorremediação de solos contaminados com hidrocarbonetos aromáticos policíclicos. Ciência Rural 37:1192-1201

30. Johansen DA (1940) Plant microtechnique. McGraw-Hill Book Company, New York, p 523

31. Khan AG (2005) Role of soil microbes in the rhizospheres of plants growing on trace metal contaminated soils in phytoremediation. J Trace Elem Med Biol 18:355-364

32. Kuiper I, Lagendijk EL, Bloemberg GV, Lugtenberg BJ (2004) Rhizoremediation: a beneficial plant-microbe interaction. Mol Plant Microbe Interact 17:6-15

33. Lacalle RG, Gomez-Sagasti MT, Artetxe U, Garbisu C, Becerril JM (2018) Brassica napus has a key role in the recovery of the health of soils contaminated with metals and diesel by rhizoremediation. Sci Total Environ 618:347-356

34. Larcher W (2000) Ecofisiologia vegetal. São Carlos, Rima Artes e Textos, $\mathrm{p} 531$

35. Lopes A, Piedade MTF (2009) Estabelecimento de Echinochloa polystachya (H.B.K.) Hitchcock (Poaceae) em solo de várzea contaminado com petróleo de Urucu. Acta Amazônica 39:583-590

36. LotfinasabasI S, Gunale VR, Rajurkar NS (2013) Petroleum Hydrocarbons Pollution in Soil and its Bioacumulation in mangrove species, Avicennia marina from Alibug Mangrove Ecosystem, Maharashtra, India. Int J Adv Res Sci Technol 2:1-7

37. Malinoski L, Maranho LT (2020) Immobilization of bacteria consortium extracted from Echinochloa polystachya (Kunth) Hitchc., Poaceae, and its potential for petroleum degradation. Braz J Dev 6:50373-50395

38. Mangwani N, Shukla SK, Kumari S, Rao TS, Das S (2014) Characterization of Stenotrophomonas acidaminiphila NCW-702 biofilm for implication in the degradation of polycyclic aromatic hydrocarbons. J Appl Microbiol 117:1012-1024

39. Maqbool F, Xu Y, Gao D, Bhatti ZA, Wang Z (2012) Soil texture effects on rhizodegradation of crude oil contaminated soil. $J$ Residuals Sci Technol 9:73-79

40. Maranho LT, Galvão F, Preussler KH, Muñiz GIB, Kuniyoshi YS (2006) Efeitos da poluição por petróleo na estrutura da folha de Podocarpus lambertii Klotzsch ex Endl., Podocarpaceae. Acta Bot Bras 20:615-624

41. Newman MM, Lorenz N, Hoilett N, Lee NR, Dick RP, Liles MR, Ramsier C, Kloepper JW (2016) Changes in rhizosphere bacterial gene expression following glyphosate treatment. Sci Total Environ 553:32-41

42. Njoku KL, Akinola MO, Oboh BO (2012) Phytoremediation of crude oil polluted soil: effect of cow dung augmentation on the remediation of crude oil polluted soil by Glycine max. J Appl Sci Res 8:277-282

43. Panchenko L, Muratova A, Ekaterina D, Golubev S, Turkovskaya $O$ (2017) Dynamics of natural revegetation of hydrocarbon-contaminated soil and remediation potential of indigenous plant species in the steppe zone of the southern Volga Uplands. Environ Sci Pollut Res 25:3260-3274

44. Parthipan E, Preetham E, Machuca LL, Rahman PKSM, Murugan K, Rajasekar A (2017) Biosurfactant and degradative enzymes mediated crude oil degradation by bacterium Bacillus subtilis A1. Front Microbiol 8:193

45. Pezeshki SR, Hester MW, Lin Q, Nyman JA (2000) The effects of oil spill and cleanup on dominant US Gulf coast marsh macrophytes: a review. Environ Pollut 108:129-139

46. Reichenauer T, Germida JJ (2008) Phytoremediation of organic contaminants in soil and groundwater. Chemsuschem 1:708-717

47. Santos JJ, Maranho LT (2018) Rhizospheric microorganisms as a solution for the recovery of soils contaminated by petroleum: a review. J Environ Manag 210:104-113

48. Tahir U, Yasmin A, Khan UH (2016) Phytoremediation: potential flora for synthetic dyestuff metabolism. J King Saud Univ 20:119-130

49. Thijs S, Sillen W, Rineau F, Weyens N, Vangronsveld J (2016) Towards an enhanced understanding of plant-microbiome interactions to improve phytoremediation: engineering the metaorganism. Front Microbiol 7:341

50. Van Hamme JD, Singh A, Ward OP (2003) Recent advances in petroleum microbiology. Microbiol Mol Biol Rev 67:503-549

51. Wenzel W (2009) Rhizosphere processes and management in plant-assisted bioremediation (Phytoremediation) of soils. Plant Soil 321:385-408

52. White PM, Wolf DC, Thoma GJ, Reynolds C (2006) Phytoremediation of alkylated polycyclic aromatic hydrocarbons in a crude oil-contaminated soil. Water Air Soil Pollut 169:207-220

53. Zhang $\mathrm{C}$, Huang $\mathrm{H}$, Zhou $\mathrm{Y}$, Lin $\mathrm{H}$, Xie T, Liao C (2019) Response of Maize (Zea mays L.) to Crude Oil Contamination in Soils. Appl Sci 9:4074

Publisher's Note Springer Nature remains neutral with regard to jurisdictional claims in published maps and institutional affiliations. 